\title{
Increasing Students' Mathematics Learning Levels via Lesson Study*
}

Meltem KOÇAK ${ }^{1}$
Ceyhun OZAN ${ }^{2}$

Remzi Y. KINCAL ${ }^{5}$

\author{
Duygu İLERITÜRK ${ }^{3}$
}

Yasin SOYLU 6
Osman BURAN ${ }^{4}$

\begin{abstract}
The aim of the study was to test the effect of teachers' professional development upon students' mathematics academic achievement levels with the help of lesson study. In this manner, the study aimed at increasing students' mathematics learning levels via lesson study. Action research was used as research method in the study. The sample of the study was consisted of $326^{\text {th }}$ - grade students who were studying at the school having lower academic success. Four different learning outcomes about "natural numbers activities" were tried to develop in the process of implementation of the study. The achievement test called as "the achievement test about natural numbers activities" was used as data collection instrument which was developed by the researchers. According to the findings of the study, there was significant difference between academic successes of the students. Lesson study is designed to support students' learning by choosing a lesson, a subject and an aim. According to the study's findings and results, it was seen that the lesson plan, research lesson, new teaching strategies and materials, which were prepared with different views altogether, made the students' learning levels and qualities increase and also develop reasoning.
\end{abstract}

Keywords: Academic success, learning, lesson study, mathematics, teaching

\section{Introduction}

Teacher's education consists of three stages i.e. pre-service, in-service and post-service teacher training. Teacher training is a process based on that teachers have gain many experiences and in service training. In this manner, in-service education and collaboration with their colleagues is inevitable part of teacher education. According to the related literature about teacher education programs, different teaching

\footnotetext{
* This study was presented as an "oral presentation" at the 7th International Congress on Curriculum and Instruction in Ankara University between 9th-12th October 2019. Furthermore, the study was supported by Atatürk University Scientific Research Projects Office

${ }^{1}$ Res. Assist., Department of Mathematics Education, Ataturk University, Turkey, meltem.kocak@atauni.edu.tr, ORCID: https://orcid.org/0000-0003-3359-2754

2 Assoc. Dr., Department of Curriculum and Instruction, Ataturk University, Turkey, ozanceyhun@atauni.edu.tr, ORCID: https://orcid.org/0000-0002-1415-7258

${ }^{3}$ Res. Assist. Dr., Department of Curriculum and Instruction, Ataturk University, Turkey, duygu.birbiri@atauni.edu.tr, ORCID: https://orcid.org/0000-0002-0409-4281

${ }^{4}$ Maths teacher., MEB, Turkey, osman830@gmail.com, ORCID: https://orcid.org/0000-0002-1922-1570

5 Prof. Dr., Department of Curriculum and Instruction, Çanakkale 18th March University, Turkey, rkincal@comu.edu.tr, ORCID: https://orcid.org/0000-0002-1922-1570

${ }^{6}$ Prof. Dr., Department of Mathematics Education, Ataturk University, Turkey, yasinsoylu@atauni.edu.tr, ORCID: https://orcid.org/0000-0002-2951-0069
} 
practices have seen to contribute to teachers' Professional development in many countries like especially Japan, Singapore, Hong Kong and United States of America (Eliahoo, 2007; Kennedy, 2005).

Spott (2009) stated that learner-centered leadership models could be more effective than the traditional Professional development models such as seminar, conference etc. Especially in Professional development. Learner-centered models enable teachers to develop according to different developmental stages like students. Moreover, lesson study, which focusses on group learning and collaboratively studying, and also use reflection and criticism, transfers teachers to researcher-teacher and encourage them for their own learning. Lesson study firstly brought out in Stigler and Hibert's (1999) study called "the teaching gap: best ideas from the word's teachers for improving education in the classroom" in USA. Then, it gained attention in Asia, Europe, Africa and Middle East countries. World Association of Lesson Study was founded in Hong Kong in 2005 and had many members from 60 different countries until 2015. According to their findings of the study, Stigler and Hiebert (1999) pointed out that any educational reforms would not be effective when they did not contribute to enrich and share teachers' knowledge and experiences in their teaching process. Therefore, policy makers and educators in USA have called for that teachers should be stimulated to use the models like lesson study which makes a transformation of teachers in learning culture and also, practice educational reforms at the classroom levels (Xu \& Pedder, 2015).

Inagaki and Sato (2012) emphasized that lesson study rooted in 1870s (Subadi, Khotimah \& Sutarni, 2013). Watanabe (2002) stated that lesson study was not only a Professional development activity but also a shared Professional culture. According to Gerot (2015), lesson study is an effective instrument to use educational reforms, and also Lewis, Perry, and Murata (2006) stated that lesson study was one of three crucial issues in educational research. Stombaugh (2013) emphasized that lesson study approach was a new paradigm which transfers teacher's learning from "learning via teaching" to "learning via understanding". Therefore, formal conversations among colleagues should be pointed out for mastering in teaching. Fullan (2007, p.297) expressed that teachers could change their profession basements like a new skill, relationship or trend when they work collaboratively with other colleagues apart from their own school. This new professional expertise has based on collaborative perspective, participatory teachers, support for research and tutor of students rather than individualism in teaching, lessons, and limitations of phenomena and control of students. Moreover Fullan (2007) stated that teachers would need to experience, enrich and give feedback about their own teaching both now and in the future.

Lesson study is called "Jugyou, which means teaching, course or course," and "Kenkyuu which means research" in Japanese language (Ermeling \& Graff-Ermeling, 2014, Lewis, 2009). It has practiced for more than 100 years in Japan, and also its roots are a complex innovation based on Confucius philosophy which is based on public teaching tradition (Norwich et al., 2014) and work with sociocultural context. Lewis and Tsuchida (1998) implied that lesson study was seen to be a factor that underlined Japanese students' international academic achievements. Moreover, Lewis and Takahashi (2013, p.207) translating the studies, which are implemented in Japon, into English language has affected other practices and studies about lesson study in different countries.

According to Lewis (2000), it gained popularity in USA and was used as an instrument in Professional development although lesson study brought out in Japan. Paine, Fang, and Wilson (2003) implied that lesson study was a key instrument for Chinese teachers to keep up with their educational reforms. 
However, lesson study has been practiced in Sweden, Great Britain, Australia, Hong Kong and Singapore (Akiba et al., 2018; Cheung \& Wong, 2014; Soto et al., 2015; Tan-Chia et al., 2013). Moreover, it is stated that there are some cultural differences its practices according to the related literature (Eraslan, 2008; Fernandez et al., 2003; Gerot, 2015; Hiebert \& Stigler, 2000). According to Gerot (2005) lesson study has three important phenomena e.g. collaboration, sustainable effort and critical reflection which are dedicated to Japanese culture. Akiba et al. (2018) defined the lesson study as a learning process via research lessons and Professional learning process relating to teaching. Therefore, teacher learning has been implied with learners' learning in Professional learning process. Teachers are active in all stages of lesson study with focusing on process, context and learners' learning as product. Teachers learning zones among the practices contribute to both teachers' Professional development and learners' learning (Coenders \& Verhoef, 2019). Collaborative Professional development models like lesson study have a significant importance on development and change of teachers' perspective in terms of learning sustainability (Akiba et al., 2018).

Lesson study is called both "ders araştırması" and "ders imecesi" in Turkish literature (Baki, 2012; Baki, Erkan, \& Demir, 2012). There is many different research about lesson study in Turkey (Akbaba-Dağ \& Doğan-Temur, 2018; Baki, 2012; Baki \& Arslan, 2014; Baki et al., 2012; Bayram \& B1kmaz, 2019; Bilge \& Dede, 2020; Boran \& Tarım, 2018; Budak et al., 2011; Bütün, 2015; Dağ, 2014; Eraslan, 2008; Erbilgin, 2013; Güner \& Akyüz, 2017; Güner \& Akyüz, 2020; Jacobs, 2012; Kıncal \& Beypınar, 2015; Serbest, 2014). TIMSS (the trends in international mathematicsh and science study) has compared 4th grade and 8the grade students' achievements in mathematics and science internationally since 1995 in Turkey. According to the results of TIMSS, Turkey has a low score and limited achievement in mathematics. Turkish students' mathematices scores were at 36th from 49 countries at 4 the grade, and 24th from 39 countries at 8th grade. So it is thought that Turkish students' mathematics success should be developed. However, the research shows that the students' achievements of mathematics from high socio-economic level was more than the students from low socio-economic level. So the students' achievements from low socio-economic level have been limited (Mullis et al., 2012).

PISA which is another international assessment system assesses the students in terms of science literacy, mathematical literacy and reading literacy. Turkey has attended to PISA each year. So, the students' scores from Turkey was below OECD average in terms of mathematical literacy according to the last PISA results. Nonetheless, Turkish students' mathematical literacy scores were commented to be limited like TIMMS mathematic results. PISA report says that socio-economic level has affected students' mathematical achievements as it expressed in TIMMS (OECD, 2016). Moreover, Ministry of National Education (MONE) PISA report expresses the need for qualified teacher education.

According to scientific data above, it could be said that mathematical education achievement in Turkey has many limitations. Solving these limitations about mathematics education is thought to be primary for educational sustainability and a healthy societal background. Shanmugam, Chinnappan and Leong (2020) stated that they assessed mathematical thinking as a mental process. Mathematics based activities which involve in different skills eg. Reasoning, analysis, synthesis, summarizing and symbolic representation include in mathematical thinking skills in problem solving process. However, it could be said that students had mathematical thinking within problem solving activities. Because, students can make permanent and significant learning with exposing to different significant environments. There can be said to be many determining variables about mathematical achievement. One of these variables is 
mathematics teacher. Monitoring mathematics teacher's mental process about their own mathematical thinking is parallel with mentoring the student' process (Shanmugam et al., 2020). According to the related literature, it could be said that teachers' quality has had crucial effect upon students' achievement (Hill et al., 2005; Riconscente, 2014). When successful and effective school system has been analyzed, it has brought out that their successes backgrounds are based on their efforts and investment in teachers' development (Rivkin et al., 2005). Therefore, it is stressed that alternative approach and methods for teachers' Professional development should be noteworthy reality for student's achievement which is the most important indicator and aim of education system. There are many alternative method and approach for teacher's professional development. One of which is lesson study approach. Lesson study enables teachers the opportunity to observe their colleagues, mutual professional development culture and learner-teacher role. It is wrong to interpret as a typical course for the course integrated in lesson study, which aims to learn students in the scope of aims and learning outcome. The course based on lesson study is research based process. Lesson study is not an instrument for supervising and assessing teacher, contrary to this it is a reflective process in which teachers work collaboratively and develop their self-learning.

In this study, it is aimed to increase students' mathematical successes via their mathematical teachers' professional developments which are crucial for mathematical success. It has been thought that this study makes a background to support teacher's professional development and to sustain mathematics education via making an educational culture based on research. Lesson study reflection on students' mathematic learning was focused on the study, and so it was related to for learning outcome about fractions. However, the study differed from other related studies in terms of it. Lesson study is considered as a support mechanism for this background. The main scope of the study is to analyze the effect of mathematics teacher's professional development via lesson study practices upon students' achievement. In this manner, it is aimed to increase students' mathematical learning levels via lesson study approach in this study. The problem below is solved in this study. Lesson study approach is important for teachers to collaborate with each other as they share their experiences and knowledge about the subject. So, this study is important to use a professional development model in teaching and learning process of mathematics. It is thought to contribute to both teachers' learning and students learning.

- Is there any significant difference among the students' learning levels about the unite "operations in natural numbers" before and after the implementation of the study?

\section{Method}

\section{Research Model}

Action research method was used in the study. Action research is a method which is used actively by teachers having a researcher role and in the process of obtaining systematic and scientific data and practices (Yıldırım \& Şimşek, 2011). Lesson study, which aims to develop the effectiveness of lessons by working with teachers collaboratively, is very common and useful in action research method. Action research firstly starts with determining the research question, and respectively preparing action plan based on theoretical framework, preparing the content of teaching programme, implementing and monitoring action plan and analyzing and assessing the implementation (Johnson, 2015). In this manner, 
lesson study has similar steps by action research step eg. planning, implantation and reflection. Therefore, firstly four outcomes which were problems for the students were determined in the study, and then related activities were prepared. Before research lesson, planned activities were assessed by research group who were teachers and experts in terms of practicability. The activities were implemented in the research lesson in later step of research implementation whether they were determined to be goal-directed or not. After research lessons, research group discussed research lessons goals and practices in terms of implementation effectiveness, and then reflection practices were done. However, the research steps were seen to be parallel with action research steps. Therefore, the research was available for using action research.

\section{Study Group}

The research was planned in the middle school whose academic success level is at low in Erzurum according to academic success ranking by Ministry of National Education. Therefore, it was implemented in the middle school, city center of Erzurum at the first semester of 2017-2018 education year. The research sample was consisted of 32 male and female students studying at $6^{\text {th }}$ grade. The criteria for the research sample were low academic successes of the students and voluntariness of students and teachers. The research sample was designed according to these criteria. So, in the scope of action research, after the first unite in which is operation in natural numbers was taught, the students who had low learning levels were determined.

\section{Research Process}

The implementations of the research were done in the scope of the unite "operations in natural numbers". Mathematics teachers taught firstly operations in natural numbers to the students at $6^{\text {th }}$ grade in the scope of action research, and then the students who had low learning levels were determined. In the next step, teachers taught these students extra two hours in a week apart from routine class hours, and in this manner, they taught the students for 6 weeks by using lesson study practices.

Lesson study steps were implemented according to Stigler and Hiebert (1999) and Norwich and Ylonen (2013) steps:

1- Defining research topic: A group of teachers work collaboratively for determining research theme. Research theme is in the scope of school, and they focus on research question which include in strengthening skill and attitude.

2- Planning the lesson: Teachers make a detailed plan for research lesson after they determine research aim and topic. Research lesson plan are designed to the assessment of former lessons.

3- Implementation and observation of the lesson: Research lesson is taught by one of the group members and, other members of the group observe the lesson. Nevertheless, the documents are collected about students learning and participation.

4- Assessment (reflection): Group members come together to discuss the research lesson on the day which is taught, and they review the lesson again according to lesson study. In this step, developing teaching process is discussed in this section rather than developing the lesson in terms of unite. Generally another observer apart from research group is invited to suggest for the lesson when they develop, implement and assess the lesson. 
5- Reorganizing the lesson: The corrections are done according to the observations and analysis of group members, and another group member is selected to teach the lesson again. Teaching the lesson again is a common practice. Another group member teaches the re-organized lesson to other students, and all steps are done again. So, the lesson is taught for many times.

\section{Data Collection Tools}

The achievement test of operations in natural numbers developed by the researchers was used as a data collection instrument. This test consisted of 40 questions each of which consisted four outcomes relating 10 questions for each of them. Six experts (three lecturer and three mathematic teachers) were offered for their consideration for contextual reliability. In accordance with their views, the last version of achievement test consisted of 40 questions and done by 100 students at $6^{\text {th }}$ grade. After the test, item analysis was done, and 20 questions in which include 5 questions for each outcomes and high item distinctiveness indexes were selected. Distinctiveness indexes of the questions were between 0.31 and 0.77. The achievement test was done as pre and post test to determine whether students learning levels increased or not. KR-20 reliability test result for achievement test was calculates as 0.83 for pre-test and 0.87 for post-test.

\section{Data Analysis}

SPSS 23 statistical program was used for data analysis. Depended groups t-test was used for determining whether students learning levels increased because the data kept for normality assumptions for both pre-test and post-test.

\section{Findings}

Depended t-test was done to determine whether the students' mathematics learning levels increased significantly or not. Table 1 shows the findings.

\section{Table 1}

The Results of Pre-Test and Post-Test about Learning Level

\begin{tabular}{lllllll}
\hline Test & $n$ & $\bar{x}$ & $s d$ & $s d t$ & $t$ & $p$ \\
\hline Pre-test & 32 & 45.31 & 21.32 & 31 & -4.294 & .000 \\
\cline { 1 - 3 } Post-test & 32 & 66.41 & 14.60 & & & \\
\hline
\end{tabular}

According to table 1, there is a significant difference between pre-test and post-test of the students ( $t=$ $4.294 ; p<0,05)$. The achievement test results of the students increased from 45.31 to 66.41. Therefore, it shows that lesson study practices increased significantly mathematics learning levels of the students. According to the observation of the study, another finding of the study is that students participated into the lesson in a more active way and also, their motivation levels were observed to increase. 


\section{Discussion}

Lesson study is designed to support students learning by choosing a lesson, topic and goal. Therefore, teachers help the students to find out concrete and significant learning for learners via supporting students' cognitive learning process. In this manner, teachers focus on the most suitable material and activities for students to make learning by walking the students' shoes. According to the results of the study, it was determined that lesson study increased significantly students' mathematics learning levels. There are many research about lesson study which increases students' academic achievement in mathematics and English language lessons (Cerbin \& Kopp, 2006; Estapa \& Nadolny, 2015; Kincal et al., 2019; Roesdiana \& Hidayati, 2020). The study result about teachers' views is parallel with the results of other studies in national and international studies.

It is seen that there is development in reasoning skills of the students when lesson plan which is prepared by many different views, research lesson, new teaching strategies and materials increase students' learning levels and learning quality. Lesson study uses different thinking ways for both learning and teaching. Therefore, teachers should have different assumptions and expectations, and accordingly learners make their own different learning assumptions and expectations. However, teachers assess learners' thoughts many times in the process. To learn students' thoughts teachers may ask the students to write their own thoughts or also they ask prompt questions to the students to say their thoughts in the classroom (Cerbin \& Kopp, 2006). However, it serves the development of the lesson. Lesson study which base on the development of collaborative teaching, serves for both teaching and also learning process (Lewis et al., 2009). Therefore, it used as a cycle which follows both teachers' Professional development and learners' learning. According to Takahashi and McDougal's (2016) study which was implemented with mathematics teachers, lesson study enabled the teachers to see their own reflections of group work in their own teaching process, and in this manner, it supported teachers to change their own views about their mathematics teaching. Lewis and Perry (2014) brought out that mathematics teachers stated lesson study increased both their own Professional knowledge and individual knowledge because they collaborated with other colleagues in the lesson study process. Specific field and pedagogical knowledge are seen to be learning and research instruments for teachers by supporting their own learning and learners' learning. Similarly, Roesdiana and Hidayati (2020) teaching with lesson study developed the students' mathematical understanding skills in terms of mathematics teaching rather than traditional teaching. So, lesson study approach is suggested to use an alternative Professional development model to increase teaching quality and students' academic achievement. The study was implemented according to the four objectives of the mathematics lesson; therefore, it should be analyzed in a much deeper way. Moreover, it makes much deeper undertandings of the academic success of the students in terms of mathematics course. Therefore, the time of the study could be increased. And also, the model of the study could be used for other teachers who have other specific field. 


\section{References}

Akbaba-Dağ, S., \& Doğan-Temur, Ö. (2018). Sınıf öğretmeni adaylarının mikro öğretim ders imecesi $\begin{array}{lllll}\text { uygulaması ile } & \text { ilgili } & \text { görüşleri. } & \text { ACJES, } & 2(2),\end{array}$ https://www.researchgate.net/publication/329174128_Sinif_Ogretmeni_Adaylarinin_Mikro_Ogreti m_Ders_Imecesi_Uygulamasi_Ile_Ilgili_Gorusleri

Akiba, M., Murata, A., Howard, C. C., \& Wilkinson, B. (2019). Lesson study design features for supporting collaborative teacher learning. Teaching and Teacher Education, 77, 352-365. DOI: 10.1016/j.tate.2018.10.012

Baki, M. (2012). Sını öğretmeni adaylarının matematĭ̆i ö̆gretme bilgilerinin gelişiminin incelenmesi: Bir ders imecesi (lesson study) çalışması (Philosophy of Doctoral Dissertation). Retrieved from CoHE Thesis Center (Thesis no: 344460).

Baki, M., \& Arslan, S. (2014). Sını öğretmeni adaylarının matematik dersini planlama bilgilerinin gelişimi: Bir ders imecesi (lesson study) örneği. XI. Ulusal Fen ve Matematik Eğitimi Kongresi'nde sunulan bildiri, Adana.

Baki, A., Erkan, İ., \& Demir, E. (2012). Ders plan etkililiğinin lesson study ile geliştirilmesi: Bir aksiyon araştırması. X.Ulusal Fen Bilimleri ve Matematik Eğitimi Kongresi'nde sunulan bildiri, Niğde.

Bayram, İ., \& Bıkmaz, F. (2019). Ders imecesi modeli ve modelin öğretmen mesleki gelişimine katkısı üzerine bir inceleme. Ankara Üniversitesi Ĕ̆itim Bilimleri Fakültesi Dergisi, 52(2), 577-610. DOI: 10.30964/auebfd.473958

Bilge, O., \& Dede, Y. (2020). Matematik öğretmenlerinin ders imecesine ilişkin görüşleri. Gazi Eğgitim Bilimleri Dergisi, 6(1), 1-22. https://dergipark.org.tr/tr/pub/gebd/issue/53429/652031

Boran, E., \& Tarım, K. (2018). Reflections of middle school teachers' Professional competency on teaching with lesson study model. International Journal of Educational Studies in Mathematics, 5(1), 2338. https://dergipark.org.tr/tr/pub/ijesim/issue/36124/397189

Borko, H., \& Putnam, R.T. (1995). Expanding a teacher`s knowledge base: A cognitive psychological perspective on professional development. In T. R. Guskey \& M. Huberman (Eds.), Professional development in education: New paradigms and practices. New York: Teachers College Press.

Budak, İ., Budak, A., Bozkurt, I., \& Kaygın, B. (2011). Matematik öğretmen adaylarıyla bir ders araştırması uygulaması. E-journal of New World Sciences Academy, 6(2), 1606-1617. https://dergipark.org.tr/tr/pub/nwsaedu/issue/19820/212088

Bulle, N. (2011). Comparing OECD educational models through the prism of PISA. Comparative Education, 47(4), 503-521. DOI: 10.1080/03050068.2011.555117

Bütün. M. (2012). İlköğretim matematik öğretmeni adaylarının uygulanan zenginleştirilmiş program sürecinde matematiği öğretme bilgilerinin gelişimi (Philosophy of Doctoral Dissertation). Retrieved from CoHE Thesis Center (Thesis no: 321920).

Carlgren, I. (2012). The learning study as an approach for 'clinical' subject matter didactic research. International Journal of Lesson and Learning Studies, 1(2), 126-139. 
https://www.researchgate.net/publication/275314292 The_learning_study_as_an_approach_for_cli nical subject matter didactic research

Cerbin, E., \& Kopp, B. (2006). Lesson study as a model for building pedagogical knowledge and improving teaching. International Journal of Teaching and Learning in Higher Education, 18(3), 250-257. https://files.eric.ed.gov/fulltext/EJ1068058.pdf

Cheung, W. M., \& Wong, W. Y. (2014). Does lesson study work?: A systematic review on the effects of lesson study and learning study on teachers and Students. International Journal for Lesson and Learning Studies, 3(2), 137-149. https:/www.emerald.com/insight/content/doi/10.1108/IJLLS-052013-0024/full/html

Coenders, F., \& Verhoef, N. (2019). Lesson study: Professional development for beginning and experienced teachers. Professional Development in Education, 45(2), 217-230. DOI: 10.1080/19415257.2018.1430050

Dağ, S. A. (2014). Mikro-öğretim ders imecesi modeli ile sınıf öğretmeni adaylarının kesir öğretim bilgilerinin geliştirilmesine yönelik bir uygulama. (Philosophy of Doctoral Dissertation). Retrieved from CoHE Thesis Center (Thesis no: 381235).

Droese, S. (2010). Lesson study in the us: Is it a mechanism for individual and organizational change? A case study of three schools (Philosophy of Doctoral Dissertation). Madison: The University of Wisconsin.

Eliahoo, R. (2017). Teacher educators: Proposing new professioanl development models within an English further education context. Professional Development in Education, 43(2), 179-193. DOI: $\underline{10.1080 / 19415257.2016 .1178164}$

Eraslan, A. (2008). Japanese lesson study: Can it work in Turkey. Education and Science, 149, 62-67. https://www.researchgate.net/publication/281407532 Japanese Lesson Study Can it work in Tu rkey Japon Ders Arastirmasi Turkiye'de Isler mi

Erbilgin, E. (2013). Sınıf öğretmenliği adaylarının ders araştırması hakkındaki görüşleri. Dicle $\begin{array}{lllll}\text { Üniversitesi Eğitim } \quad \text { Fakültesi } & \text { 69-73. }\end{array}$ https://dergipark.org.tr/tr/pub/zgefd/issue/47941/606520

Ermeling, B. A., \& Graff-Ermeling, G. (2014). Learning to learn from teaching: A first-hand account of lesson study in Japan. International Journal for Lesson and Learning Studies, 3(2), 170-191.

Estapa, A., \& Nadolny, L. (2015). The effect of an augmented reality enhanced mathematics lesson on student achievement and motivation. Journals of STEM Education, 16(3), 40-48. https://eric.ed.gov/?id=EJ1078415

Fernandez, C., Cannon, J., \& Chokshi, S. (2003). A U.S.-Japan lesson study collaboration reveals critical lenses for examining practice. Teaching and Teacher Education, 19, 171-185. https://www.researchgate.net/publication/222707874_A_USJapan lesson study collaboration reveals critical lenses for examining practice

Fullan, M. (2007). The meaning of educational change (4th ed.). Teachers College Press, NY: U.S. 
Gerot, G. (2015). The prospects of lesson study in the US. International Journal for Lesson and Learning Studies, 4(1), 7-25. $\quad$ https://www.emerald.com/insight/content/doi/10.1108/IJLLS-02-2014$\underline{0007 / f u l l / h t m l ? j o u r n a l C o d e=i j l l s}$

Grosso de Leon, A. (2001). Higher education's challenge: New teacher education models for a new century. New York: Carnegie Corporation of New York.

Güner, P., \& Akyüz, D. (2017). Ders imecesi (lesson study) mesleki gelişim modeli: Öğretmen adaylarımın fark etme becerilerinin incelenmesi. İlköğretim Online, 16(2), 428-452. DOI: 10.17051/ilkonline.2017.304709

Halvorsen, A. L., \& Lund, A.K. (2013). Lesson study and history education. The Social Studies, 104(3), 123-129. DOI: $10.1080 / 00377996.2012 .698326$

Hiebert, J., \& Stigler, J. W. (2000). A proposal for improving classroom teaching: Lessons from the TIMSS video study. The Elementary School Journal, 101(1), 3-20. https://www.jstor.org/stable/1002332?seq=1\#metadata_info_tab_contents

Hill, H. C., Rowan, B., \& Ball, D. L. (2005). Effects of teachers' mathematical knowledge for teaching on student achievement. American Educational Research Journal, 42(2), 371. DOI: $\underline{10.3102 / 00028312042002371}$

Inprasitha, N. (2014). Perceptions on professional development of supervisors in the non-project and Project schools using Lesson Study. Procedia-Social and Behavioral Sciences, 116, 2069-2073. DOI: 10.1016/j.sbspro.2014.01.521

Jacobs, D. B. (2012). Japonya'da fen ve fizik öğretmenlerinin mesleki gelişimi ve mesleki gelişiminde Japon yaklaşımı: Ders araştırması. Ankara Üniversitesi Ĕ̆itim Bilimleri Fakültesi Dergisi, 45(2), 33-54. https://atif.sobiad.com/index.jsp?modul=makaledetay\&Alan=sosyal\&Id=AWgYvPzyHDbCZb_mR FTA

Johnson, A. P. (2015). Eylem Araştırması El Kitabı (Çev. Y. Uzuner, Y. \& M. Özten Anay). Ankara: Anı Yayıncilik.

Kennedy, A. (2005). Models of continuing professionl development: A framework for analysis. Journal of In-service Education, 31(2), 235-250. DOI: 10.1080/13674580500200277

Kıncal, R. Y., \& Beypınar, D. (2015). Ders araştırması uygulamasının matematik öğretmenlerinin mesleki gelişimlerine ve öğrenme sürecinin geliştirilmesine etkisi. Mehmet Akif Ersoy Üniversitesi Eğitim Fakültesi Dergisi, 33, 186- 210. https://dergipark.org.tr/tr/pub/maeuefd/issue/19406/206353

Kıncal, R. Y., Ozan, C., \& İleritürk, D. (2019). Increasing students English language learning levels via lesson study. English Language Teaching, 12, 88-95. DOI: 10.5539/elt.v12n9p88

Lewis, C. (2000). Lesson study: The core of Japanese professional development. Paper presented at the annual meeting of the American Educational Research Association, New Orleans: U.S.

Lewis, C. (2009). What is the nature of knowledge development in lesson study?. Educational Action Research, 17(1), 95-110. DOI: 10.1080/09650790802667477 
Lewis, C. C., Perry, R. R., \& Hurd, J. (2009). Improving mathematics instruction through lesson study: A theoretical model and North American case. Journal of Math Teacher Education, 12, 285-304. DOI: 10.1007/s10857-009-9102-7

Lewis, C. C. \& Perry, R. R. (2014). Lesson study with mathematical resources: A sustainable model for locally-led teachers Professional learning. Mathematics Teacher Education and Development, 16, 1-20. https://eric.ed.gov/?id=EJ1046670

Lewis, C., \& Takahashi, A. (2013). Facilitating curriculum reforms through lesson study. International Journal for Lesson and Learning Studies, 2(3), 207-217. DOI: 10.1108/IJLLS-01-2013-0006

Lewis, C., \& Tsuchida, I. (1998). A lesson is like a swiftly flowing river. American Educator, 22(4), 14-17 and 50-52. DOI: $10.1177 / 136548029900200117$

Lim, C., Lee, K. E. C., Saito, E., \& Syed-Haron, S. (2011). Taking stock of lesson study as a platform for teacher development in Singapore. Asia-Pacific Journal of Teacher Education, 39(4), 353-365. DOI: 10.1080/1359866X.2011.614683

Lo, M., Pong, W. Y., \& Pakey, C. P. M. (2005). For each and everyone. Catering for individual differences through learning studies. Hong Kong University Press: Hong Kong.

Lucenario, J. L. S., Yangco, R. T., Punzalan, A. E., \& Espinosa, A. A. (2016). Pedagogical content knowledge-guided lesson study: Effects on teacher competence and students' achievement in chemistry. Education Research International, 1-9. DOI: 10.1155/2016/6068930

Luukkainen-Harju, H., Vettenranta, J., Soivio-Ouakrim, N., \& Bernelius, V. (2016). Differences between students' PISA reading literacy scores and grading for mother tongue and literature at school: A geostatistical analysis of the Finnish PISA 2009 data. Education Inquiry, 7(4), 463-479. DOI: 10.3402/edui.v7.29413

Mullis, I. V. S., Martin, M. O., Foy, P., \& Arora, A. (2012). TIMSS 2011 International results in mathematics. International Association for the Evaluation of Educational Achievement (IEA). TIMSS \& PIRLS International Study Center.

Nami, F., Marandi, S. S., \& Sotoudehnama, E. (2016). CALL teacher professional growth through lesson study practice: An investigation into EFL teachers' perceptions. Computer Assisted Language Learning, 29(4), 658-682. DOI: 10.1080/09588221.2015.1016439

Norwich, B, Dudley, P., \& Ylonen, A. (2014). Using lesson study to assess pupils' learning difficulties. International Journal for Lesson and Learning Studies, 3(2), 192-207. DOI: 10.1108/IJLLS-12-2013-0059

Norwich, B., \& Ylonen, A. (2013). Design based research to develop the teaching of pupils wiht moderate learning difficulties (MLD): Evaluating lesson study in terms of pupil, teacher and school outcomes. Teaching and Teacher Education, 34, 162-173. DOI: 10.1016/j.tate.2013.04.012

OECD. (2016). PISA 2015 results. Retrived from https://www.oecd.org/pisa on 01.02.2017

Paine, L.W., Fang, Y., \& Wilson, S. (2003). Entering a culture of teaching. In Britton, E., Paine, L., Pimm, D., \& Raizen, S. (Eds.), Comprehensive teacher induction: Systems for early career learning (pp. 20-82). Kluwer, Dordrecht. 
Phillips, J. (2003). Powerful learning: Creating learning communities in urban school reform. Journal of Curriculum and Supervision, 240-258. https://www.researchgate.net/publication/242092950_Powerful_Learning_Creating_Learning_Com munities in Urban School Reform

Roesdiana, L., \& Hidayati, N. (2020). The effectiveness of lesson study on student learning outcomes in the study of mathematics education issues. Sriwijaya International Journal of Lesson Study, 1(1), 25-30. DOI: $10.36706 /$ sij-ls.v1i1.8

Riconscente, M. M. (2014). Effects of perceived teacher practices on Latino high school students' interest, self-efficacy, and achievement in mathematics. The Journal of Experimental Education, 82(1), 51-73. DOI: $10.1080 / 00220973.2013 .813358$

Rivkin, S. G., Hanushek, E. A., \& Kain, J. F. (2005). Teachers, schools, and academic achievement. Econometrica, 73(2), 417 - 458.

Roberts, M. (2010). Lesson study: Professional development and its impact on science teacher self-efficacy (Doctoral dissertation). New York: Columbia University.

Serbest, A. (2014). Ders imecesinin etki alanları üzerine bir meta-sentez çalışması (Philosophy of Doctoral Dissertation). Retrieved from CoHE Thesis Center (Thesis no: 381062).

Shanmugam, S. K. S., Chinnappan, M., \& Leong, L. E. (2020). Action research in examining the enquiry approach of lesson study in mathematics. Social Sciences $\mathcal{E}$ Humanites, 28(3), 1675-1693. http://www.pertanika.upm.edu.my/resources/files/Pertanika\%20PAPERS/JSSH\%20Vol.\%2028\%20( 3)\%20Sep.\%202020/05\%20JSSH-4813-2019.pdf

Soto, E., Servan, M. J., \& Perez, A. I. (2015). Cooperative research. A critical strategy in university teacher training. A case study of lesson and learning studies. International Journal for Lesson and Learning Studies, 4(1), 56-71. DOI: 10.1108/IJLLS-05-2014-0011

Spott, R. A. (2019). Factors that foster and deter advanced teachers' professional development. Teaching and Teacher Education, 77, 321-331. DOI: 10.1016/j.tate. 2018.11.001 0742-051X

Stigler, J. W., \& Hiebert, J. (1999). The teaching gap: Best ideas from the world's teachers for improving education in the classroom. New York, NY: Summit Books.

Stombaugh, A., Sperstad, R., VanWormer, A., Jennings, E., \& Vogh, B. (2013). Using lesson study to integrate information literacy throughout the curriculum, Nurse Educator, 38(4), 173-177. DOI: 10.15845/noril.v8i1.262

Subadi, T., Khotimah, R. P., \& Sutarni, S. (2013). A lesson study as a development model of professional teachers. International Journal of Education, 5(2), 102-114. DOI: 10.5296/ije.v5i2.3831

Takahashi, A., \& McDougal, T. (2016). Collaborative lesson research: Maximizing the impact of lesson study. ZDM Mathematics Education, 48, 513-56. DOI: 10.1007/s11858-015-0752-x

Tan-Chia, L., Fang, Y., \& Ang, P. C. (2013). Innovating the Singapore English language curriculum through lesson study. International Journal for Lesson and Learning Studies, 2(3), 256-280. DOI: 10.1108/IJLLS-03-2013-0017 
Teddlie, C., \& Tashakkori, A. (2009). Foundations of mixed methods research: Integrating quantitative and qualitative approaches in the social and behavioral sciences. Thousand Oaks, CA: Sage.

Tepetaş, Ş., \& Tezcan, T. (2020). Evaluation of parent reflections after lesson study implementation with preschool teachers. Erzincan Üniversitesi Eğitim Fakültesi Dergisi, 22(2), 447-463. DOI: 10.17556/erziefd.643341

Vogt, F., \& Rogella, M. (2009). Developing adaptive teaching competency through coaching. Teaching and Teacher Education, 25(8), 1051-1060. DOI: 10.1016/j.tate.2009.04.002

Watanabe, T. (2002). Learning from Japanese lesson study. Educational Leadership, 59(6), 36-39. https://www.researchgate.net/publication/285749757_Learning_from_Japanese_lesson_study

Xu, H., \& Pedder, D. (2015). Lesson study: An international review of the research. In P. Dudley (Ed.), Lesson study: Professional learning for our time (pp. 29-59). Routledge, NY: US.

Yıldırım, A., \& Şimşek, H. (2011). Sosyal bilimlerde nitel araştırma yöntemleri (8.baskı). Ankara: Seçkin Yayınevi. 